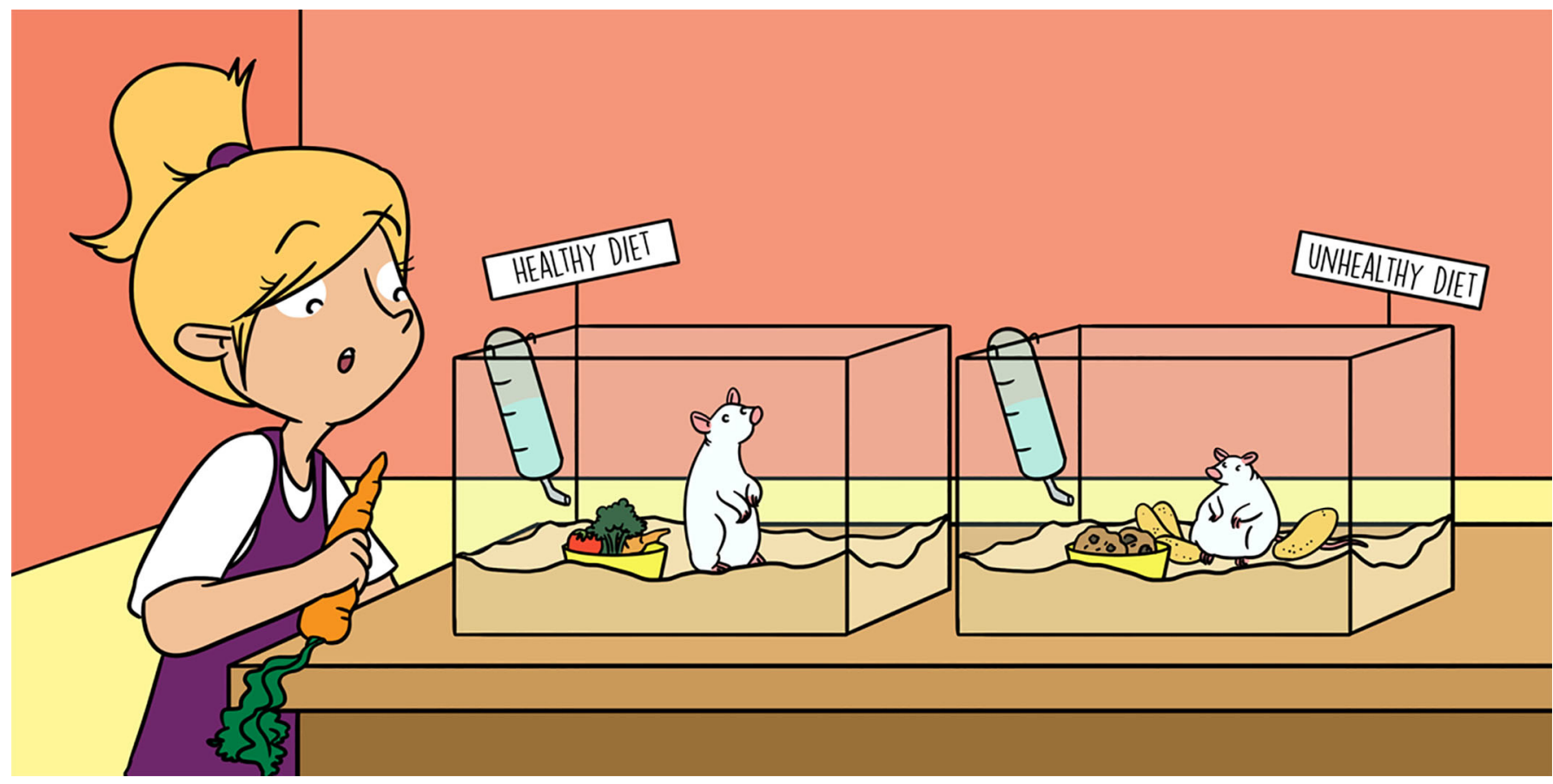

\title{
FROM MICE TO HUMANS: THE STUDY OF OBESITY
}

\section{Katharina Weiper, Sabine Weiskirchen and Ralf Weiskirchen *}

Institute of Molecular Pathobiochemistry, Experimental Gene Therapy and Clinical Chemistry (IFMPEGKC), RWTH University Hospital Aachen, Aachen, Germany

\section{YOUNG REVIEWERS:}

MEDIUM

SCHOOL

PARINI-

MERELLO

AGE: 12

\section{OBESITY}

Excessive fat accumulation in the body that presents a risk to health. Body mass index (BMI) is used to determine obesity. BMI is defined as a person's weight (in $\mathrm{kg}$ ) divided by the square of his height (in meters). A person with a BMI of $30 \mathrm{~kg} / \mathrm{m}^{2}$ or more is generally considered obese, while a BMI between 25
Do you love eating as much as we do? Why do delicious, sweet, and fatty foods make us overweight? And what makes being overweight so unhealthy? Many scientists ask themselves these questions every day. In order to find out what happens in the cells of the body and what makes us obese and sick, animal experiments on mice are necessary.

\section{WHY IS OBESITY SUCH A PROBLEM?}

Obesity is a growing health problem all over the world. Obesity is more severe than just being overweight. Obesity is defined as a medical condition in which excess body fat has accumulated to an extent causing adverse effects on health. Importantly, more and more children are becoming overweight and the prevalence of obesity in children has increased dramatically [1]. Worldwide, an estimated 41 million kids under the age of 5 are overweight or obese [2]. Obesity leads to a greater chance of dying young. Returning to a normal weight from obesity is difficult, and children with excess weight are more likely to become obese as they get older [1]. When people become obese at 
and $29.9 \mathrm{~kg} / \mathrm{m}^{2}$ indicates overweight. BMls of $18.5-25 \mathrm{~kg} / \mathrm{m}^{2}$ indicate a healthy weight, while underweight is defined as a BMI lower $18.5 \mathrm{~kg} / \mathrm{m}^{2}$.

\section{KILOCALORIE}

A measure of energy. Per definition, one calorie (cal) is the amount of energy required to heat $1 \mathrm{ml}$ of water by $1^{\circ} \mathrm{K}$. One thousand calories is equal to 1

kilocalorie (kcal).

\section{TYPE 2 DIABETES}

A medical condition in which your body is not able to effectively use insulin to bring glucose into your cells.

\section{INSULIN}

Small molecule that regulates the use of sugars, fats, and proteins in the body by promoting the absorption of sugars from the blood into liver, fat, and muscle cells.

\section{Figure 1}

Calories in everyday foods. The calorie content per $100 \mathrm{~g}(\sim 3.5$ $\mathrm{oz}$ ) or $100 \mathrm{ml}$ of each food is shown. It is important to consider the portion sizes of the food when calculating the total kcal intake. For example, a whole pizza typically has a weight of $350 \mathrm{~g}(\sim 12.35 \mathrm{oz})$, which corresponds to $875 \mathrm{kcal}$ an older age they might not see as many ill effects, because it takes up to 15-25 years until an obese person gets really sick or suffers from obesity-related diseases, such as diabetes [3]. However, if children are obese, they will get these complications when they are young adults. The main reasons that people gain weight are because they eat too much, they eat unhealthy foods, and they do not get enough physical activity. Fast food and sweets containing too much fat, sugar, and salt are the main "bad guys" that lead to obesity and the diseases that it causes.

\section{WHAT HAPPENS IN THE BODY WHEN A PERSON BECOMES OBESE?}

Kids need different amounts of energy, depending on their age, size, sex, and level of physical activity. Energy is measured in a unit called the kilocalorie (kcal). Typically, a kid between 6- and 14-years old needs 1,200-2,000 kcals per day [4]. Taking in more kcals leads to gradual and persistent fat built-up and weight gain if the kcals are not burned off by additional exercise. For example, six gummy bears have about $28 \mathrm{kcal}$ and $100 \mathrm{~g}$ chocolate has about $500 \mathrm{kcal}$ (Figure 1). To get rid of $200 \mathrm{kcal}$, you have to ride a bike for about $60 \mathrm{~min}$.

Diseases arising from obesity include type 2 diabetes, stroke, depression, or heart disease [5]. Diabetes is a disease that results from high levels sugar in the blood. After we eat sugar, our bodies release a hormone called insulin, which helps muscle and fat cells to take up and store sugar. This is important because our cells and organs can convert sugar into the energy needed to grow and keep the body active and fit. As long as the fat tissue can store extra energy, everything is fine. However, if we eat too much, the insulin machinery is overstrained and the extra sugar circulates in the bloodstream, leading to disease. If blood sugar levels are not controlled, you could set yourself up for a host of complications including damage of nearly

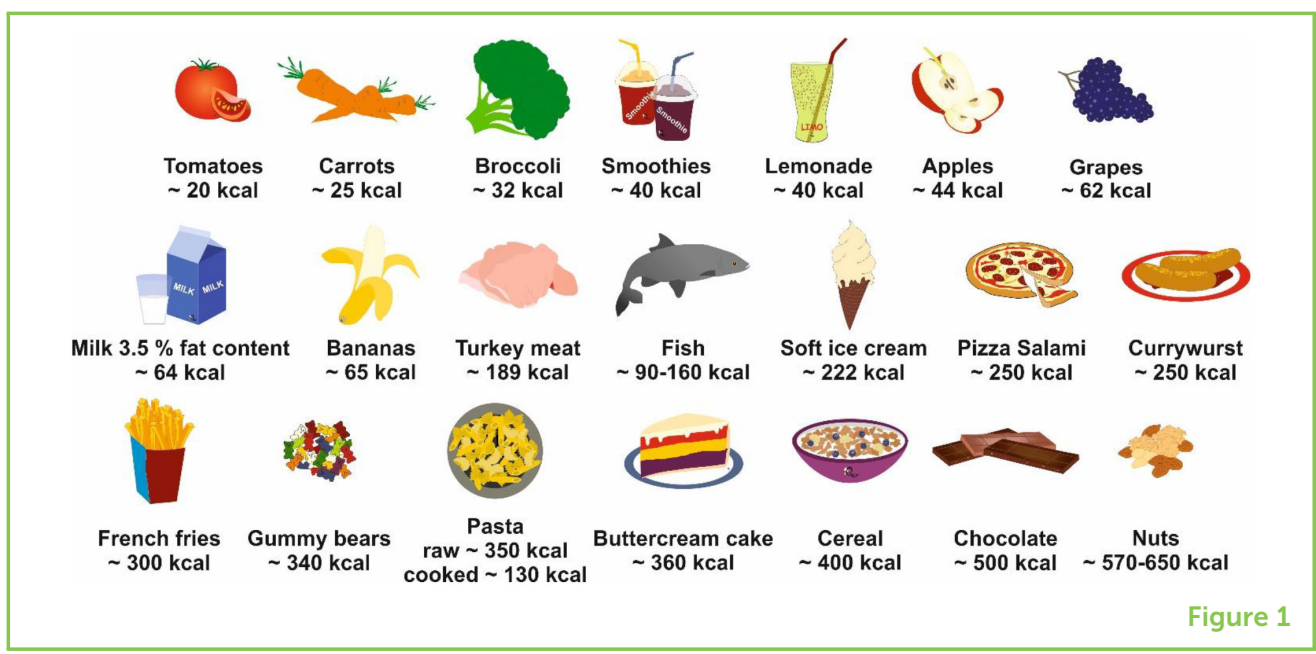




\section{METABOLIC}

\section{SYNDROME}

A cluster of at least 4 of the following 5 conditions: obesity, high blood pressure, high blood sugar, high triglycerides and high cholesterol every organ. Also, heart attacks, liver diseases, and many other health problems can result from diabetes. The cells of the body can also become insensitive toward insulin and no longer absorb the sugar. That is the start type 2 diabetes. This is a serious disease that severely impacts the quality of life, because diabetics must carefully consider what they eat and must regularly inject insulin to control their blood sugar levels. In 2017, 1 in 11 people in the world had diabetes and the frequency of diabetes keeps increasing steadily each year.

Similarly, eating too much fat can also be a health threat. Under normal conditions, fat is transported from the blood into the liver and used as fuel to produce energy for the body. However, if too much fat is eaten, a person can become overweight, particularly in the stomach area, and develop high blood pressure, insulin resistance, and heart disease. Since these dangerous medical conditions often occur together in obese people, the conditions as a group are called metabolic syndrome.

\section{WHAT HAVE SCIENTISTS DONE TO UNDERSTAND WHAT HAPPENS IN THE BODY DURING OBESITY?}

So, now you can see why it is very important to understand what happens in the body when an excess of nutrients leads to health problems, including type 2 diabetes and metabolic syndrome. Scientists and doctors are working hard to understand this disease process and to find ways to help obese people.

To do this, scientists investigate things like the differences between lean and obese people, the way insulin works at the molecular level, and the harmful effects of excess sugars and fats on health. These findings help scientists to design specific drugs that help to treat the dangerous health conditions seen in obese patients.

\section{MOUSE MODELS OF OBESITY}

For understanding complex health issues like obesity and testing new drugs to treat various health conditions, animal models are necessary. Although many experiments can be done in isolated cells, other experiments require a more complex system, like living animals. Ideally, animal models should closely mimic the human situation. Mice are the most widely used animal models in biomedical research. Mouse and human cells are similar in the ways they grow, divide, and perform specific functions like breaking down food. Mice and humans have the same organs and their bodies work in much the same way, and they are also very similar in the way they develop diseases like obesity. On top of that, mice are small, easily housed and maintained, and reproduce quickly. Overall, research on mice is a very important tool to learn about how the body works, how a human being gets sick, and whether new drugs are safe and effective [6]. 


\section{Figure 2}

High energy intake can result in obesity. Eating too many high-fat and high-sugar foods is a major cause of obesity, especially if we take in more calories than we burn off through physical activity. Based on their impact on health and disease, food products can be classified as "good" and "bad" for us. In general, unprocessed food products are healthy and have low calories, while high-sugar foods and fast foods contain a lot of calories.

\section{GENETICALLY} MODIFIED

An organism whose genetic material (DNA) has been artificially altered by humans in order to study the effects of specific genes on things like the development of certain diseases.

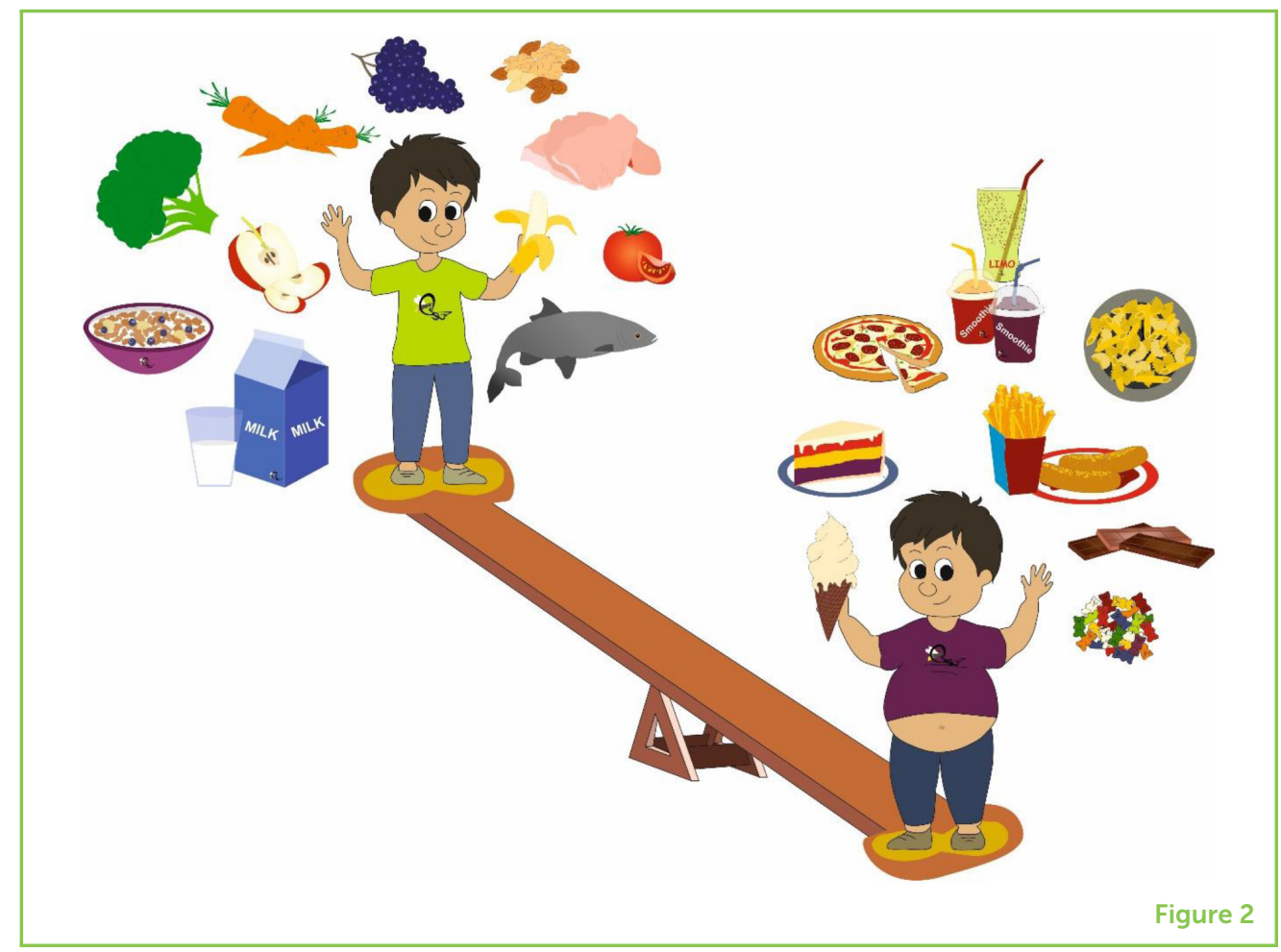

Mice are also great experimental tools because they can be genetically modified, meaning that their genes can be changed to make them more susceptible to specific diseases, such as obesity or cancer. Mice will also eat everything they are given, even if the food is unhealthy. This is especially useful when investigating why people gain weight, why obesity makes us sick, and how we can modify our diets to stay healthy. So, we can feed mice food that mimics an unbalanced diet in humans. Using this approach, many studies have shown that high intake of fat and sugar leads to weight gain in both mice and humans, increasing the risk of becoming sick (Figure 2).

Scientists have found that mice fed sugar- or fat-enriched diets for long time end up with diseases like humans: obesity, high blood sugar, high blood pressure, insulin resistance, heart failure, and liver disease [7].

Several important discoveries about obesity have recently been made using mice. These include the unraveling of mechanisms leading to obesity, altered glucose metabolism, and failures in insulin function. Moreover, mice are used to test novel drug formulations and to identify risk factors of obesity.

\section{CONCLUSIONS}

Obesity has many negative effects on health. Obesity is most commonly caused by excessive food intake, lack of physical activity, 
Figure 3

From mice to man. In biomedical research, mice are used to understand human diseases. Although mice and humans look quite different from each other, many features related to health and disease are the same. This is why mice are one of the most commonly used model organisms in human disease research.

\section{Similarities}

- Organ sytems

- Growth, replication, differentiation and death

- Analogy in disease initiation and progression

- Adaptability to environment

- Eating of plant and animal components

- Pathways in degrading food

\section{Differences}

- Outer appearance

- Body size (11 cm vs. $1.8 \mathrm{~m})$

- Body mass (25 g vs. $80 \mathrm{~kg}$ )

- Maximum lifespan (2-3 years vs. 75-80 years)

- Daily rhythm (night vs. day)

- Number of descendants

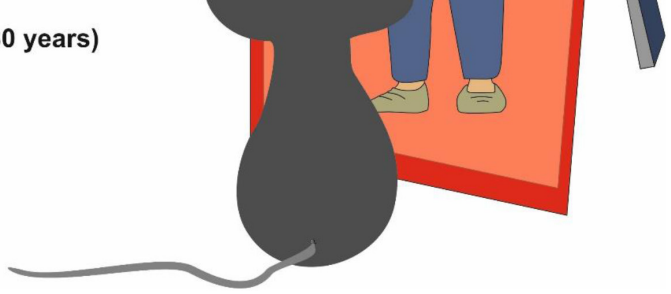

Figure 3

and genetic predisposition. Obese people often suffer from diseases like heart failure and liver disease and can even die from them. Mice fed healthy or harmful diets are ideal experimental models to study the way the food we eat can affect our weight and our health. In addition, mice can be used to study ways to prevent or treat obesity and its related diseases. Mouse studies can help scientists understand the underlying pathways contributing to obesity and to develop new drugs. There has always been debate about using animals for research. We know that animals can suffer like humans and many people object to animal research for this reason [8]. Also, even though mice and humans are similar in some ways, a mouse is definitely not a human. The results obtained in mice do not always reliably predict the reality in patients (Figure 3). However, we should keep in mind that research findings obtained in mice help to save and improve the lives of millions of people. Since more and more people, including children, are becoming overweight, it is necessary to continue research on obesity, to understand the processes that happen in the body as people become obese and to develop novel medications to prevent or treat this disease.

\section{AUTHOR CONTRIBUTIONS}

KW has written the first draft. SW generated the figures. RW edited the manuscript. All authors contributed to the article and approved the submitted version. 


\section{REFERENCES}

1. Di Cesare, M., Sorić, M., Bovet, P., Miranda, J. J., Bhutta, Z., Stevens, G. A., et al. 2019. The epidemiological burden of obesity in childhood: a worldwide epidemic requiring urgent action. BMC Med. 17:212. doi: 10.1186/s12916-01 9-1449-8

2. World Health Organization (WHO). 2020. Obesity and Overweight. Available online at: https://www.who.int/en/news-room/fact-sheets/detail/obesity-and -overweight (accessed July 9, 2020).

3. Shahbazian, H., and Rezaii, I. 2013. Diabetic kidney disease; review of the current knowledge. J. Renal Inj. Prev. 2:73-80. doi: 10.12861/jrip.2013.24

4. Office of Disease Prevention and Health Promotion (DPHP). 2015. Dietary Guidelines 2015-2020. Available online at: https://health.gov/ dietaryguidelines/2015/guidelines/appendix-2/ (accessed July 9, 2020).

5. Guh, D. P., Zhang, W., Bansback, N., Amarsi, Z., Birmingham, C. L., and Anis, A.H. 2009. The incidence of co-morbidities related to obesity and overweight: a systematic review and meta-analysis. BMC Public Health 9:88. doi: 10.1186/1471-2458-9-88

6. Piernas, C., and Popkin, B. M. 2011. Food portion patterns and trends among U.S. children and the relationship to total eating occasion size, 1977-2006. J. Nutr. 141:1159-64. doi: 10.3945/jn.111.138727

7. Wong, S. K., Chin, K. Y., Suhaimi, F. H., Fairus, A., and Ima-Nirwana, S. 2016. Animal models of metabolic syndrome: a review. Nutr. Metab. (Lond). 13:65. doi: 10.1186/s12986-016-0123-9

8. Pro \& Cons of Current Issues. 2020. Should Animals Be Used for Scientific or Commercial Testing? Available online at: https://animal-testing.procon.org/ (accessed July 9, 2020).

SUBMITTED: 05 December 2019; ACCEPTED: 11 June 2020; PUBLISHED ONLINE: 28 July 2020.

EDITED BY: Jorge Galindo-Villegas, Nord University, Norway

CITATION: Weiper K, Weiskirchen S and Weiskirchen R (2020) From Mice to Humans: The Study of Obesity. Front. Young Minds 8:92. doi: 10.3389/frym.2020. 00092

CONFLICT OF INTEREST: The authors declare that the research was conducted in the absence of any commercial or financial relationships that could be construed as a potential conflict of interest.

COPYRIGHT @ 2020 Weiper, Weiskirchen and Weiskirchen. This is an open-access article distributed under the terms of the Creative Commons Attribution License (CC BY). The use, distribution or reproduction in other forums is permitted, provided the original author(s) and the copyright owner(s) are credited and that the original publication in this journal is cited, in accordance with accepted academic practice. No use, distribution or reproduction is permitted which does not comply with these terms. 


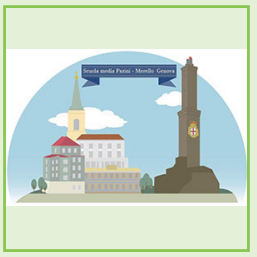

\section{YOUNG REVIEWERS}

\section{MEDIUM SCHOOL PARINI-MERELLO, AGE: 12}

We are four classes (2A, 2B, 2E, 2F) of the Medium School Parini-Merello of Genova. Thanks to our teachers, the school is involved in many projects, and we are lucky to have many exciting experiences! The Frontiers for Young Minds project was one of the best: we thought that it would have been a very challenging job, but once we started working all together, we had so much fun, and our curiosity helped us in carrying out the review work!

\section{AUTHORS}
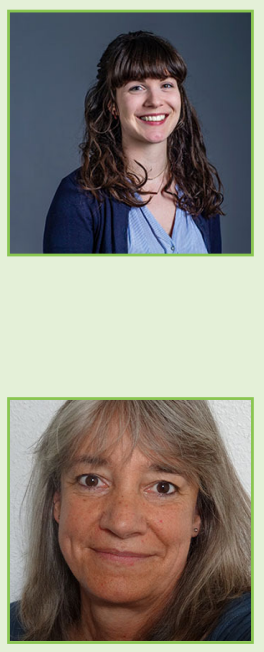

\section{KATHARINA WEIPER}

Katharina is just finishing her studies of nutritional science at the University of Potsdam. She will then do her doctorate in biochemistry, where she is primarily interested in which foods lead to diseases or how classical medicine can be influenced by nutrition. When Katharina is not in the lab, she prefers to be outside and enjoys hiking with her boyfriend, being at the waterfront or spending evenings with friends.

\section{SABINE WEISKIRCHEN}

After attending primary school and high school, Sabine made training as medical-technical assistant and worked in diagnostic laboratories and biochemical institutes in Mettmann (Germany), Cologne (Germany), Innsbruck (Austria), and presently in Aachen (Germany). In her professional career, she became familiar with a variety of biomedical analysis techniques. She likes her home football team (Borussia VfL 1900 Mönchengladbach), gardening, and prefer to listen to the music of Bon Jovi.

\section{RALF WEISKIRCHEN}

Ralf is a Biologist currently working as a Professor at the University Hospital Aachen in Germany. In his research projects, he is focusing on understanding the development of liver disease and how this knowledge can be used to establish novel therapies. Beyond his passion for science, Ralf listens to the music of the Beatles, watches football, and likes traveling. *rweiskirchen@ukaachen.de 